\title{
Front Matter: Volume 6718
}

, "Front Matter: Volume 6718," Proc. SPIE 6718, Optomechatronic ComputerVision Systems II, 671801 (11 October 2007); doi: 10.1117/12.775802

EDent: International Symposium on Optomechatronic Technologies, 2007, SPIE. Lausanne, Switzerland 


\title{
PROCEEDINGS OF SPIE
}

\section{Optomechatronic Computer-Vision Systems II}

\author{
Jonathan Kofman \\ Yuri Lopez de Meneses \\ Shun'ichi Kaneko \\ Claudio A. Perez \\ Didier Coquin \\ Editors
}

\section{8-10 October 2007}

Lausanne, Switzerland

Organized by

Ecole Polytechnique Fédérale de Lausanne (Switzerland)

Sponsored by

LIST-Laboratoire d'Intégration des Systèmes et des Technologies, CEA (France)

CSEM-Centre Suisse d'Electronique et de Microtechnique SA (Switzerland)

IMT-Institut de microtechnique (France)

Olympus (Switzerland)

Taylor \& Francis Group (United Kingdom)

Cooperating Organizations

FSRM-Fondation Suisse pour la Recherche en Microtechnique (Switzerland)

SPIE

Published by

SPIE

Volume 6718 
The papers included in this volume were part of the technical conference cited on the cover and title page. Papers were selected and subject to review by the editors and conference program committee. Some conference presentations may not be available for publication. The papers published in these proceedings reflect the work and thoughts of the authors and are published herein as submitted. The publisher is not responsible for the validity of the information or for any outcomes resulting from reliance thereon.

Please use the following format to cite material from this book:

Author(s), "Title of Paper," in Optomechatronic Computer-Vision Systems II, edited by Jonathan Kofman, Yuri Lopez de Meneses, Shun'ichi Kaneko, Claudio A. Perez, Didier Coquin, Proceedings of SPIE Vol. 6718 (SPIE, Bellingham, WA, 2007) Article CID Number.

ISSN 0277-786X

ISBN 9780819468666

Published by

SPIE

P.O. Box 10, Bellingham, Washington $98227-0010$ USA

Telephone +1 3606763290 (Pacific Time) · Fax +1 3606471445

SPIE.org

Copyright (c) 2007, Society of Photo-Optical Instrumentation Engineers

Copying of material in this book for internal or personal use, or for the internal or personal use of specific clients, beyond the fair use provisions granted by the U.S. Copyright Law is authorized by SPIE subject to payment of copying fees. The Transactional Reporting Service base fee for this volume is $\$ 18.00$ per article (or portion thereof), which should be paid directly to the Copyright Clearance Center (CCC), 222 Rosewood Drive, Danvers, MA 01923. Payment may also be made electronically through CCC Online at copyright.com. Other copying for republication, resale, advertising or promotion, or any form of systematic or multiple reproduction of any material in this book is prohibited except with permission in writing from the publisher. The CCC fee code is $0277-786 \mathrm{X} / 07 / \$ 18.00$.

Printed in the United States of America.

Publication of record for individual papers is online in the SPIE Digital Library.

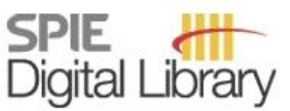

SPIEDigitalLibrary.org

Paper Numbering: Proceedings of SPIE follow an e-First publication model, with papers published first online and then in print and on CD-ROM. Papers are published as they are submitted and meet publication criteria. A unique, consistent, permanent citation identifier (CID) number is assigned to each article at the time of the first publication. Utilization of CIDs allows articles to be fully citable as soon they are published online, and connects the same identifier to all online, print, and electronic versions of the publication. SPIE uses a six-digit CID article numbering system in which:

- The first four digits correspond to the SPIE volume number.

- The last two digits indicate publication order within the volume using a Base 36 numbering system employing both numerals and letters. These two-number sets start with 00, 01, 02, 03, 04, 05, $06,07,08,09,0 \mathrm{~A}, 0 \mathrm{~B} \ldots \mathrm{OZ}$, followed by $10-1 \mathrm{Z}, 20-2 \mathrm{Z}$, etc.

The CID number appears on each page of the manuscript. The complete citation is used on the first page, and an abbreviated version on subsequent pages. Numbers in the index correspond to the last two digits of the six-digit CID number. 


\title{
Contents
}

\author{
$\checkmark$ Conference Committee \\ vii Symposium Committee \\ ix Introduction
}

SESSION 1 IMAGE FOCUS, ENHANCEMENT, DISTORTION, AND ENCODING

671802 Matching-based focusing by orientation code matching and depth reconstruction [6718-08]

Y. Li, H. Takauji, S. Kaneko, T. Tanaka, Hokkaido Univ. (Japan); I. Ohmura, Hikkaido Industrial Research Institute (Japan)

671803 Flexible depth of field extension and its application to multiple micro objects recognition [6718-09]

D. Hong, K. Park, H. Cho, Korea Advanced Institute of Science and Technology (South Korea)

671804 Distortion and scale estimation for robust fag registration [6718-16]

I. Nakayama, H. Takauji, S. Kaneko, T. Tanaka, Hokkaido Univ. (Japan)

\section{SESSION 2 3D RANGE SENSING AND IMAGING}

671808 Measurement of partially specular objects by controlling imaging range [6718-11] J. Jeong, D. Hong, H. Cho, Korea Advanced Institute of Science and Technology (South Korea)

6718 0A Multiple-line full-field laser-camera range sensor [6718-23]

J. Kofman, Univ. of Waterloo (Canada) and Univ. of Ottawa (Canada); J. T. Wu, Univ. of Ottawa (Canada); K. Borribanbunpotkat, Univ. of Waterloo (Canada)

$6718 \mathrm{OB}$ Self-localization of a mobile robot using a single vision sensor [6718-21]

J. Shim, Korea Polytechnic Univ. (South Korea)

\section{SESSION 3 NOVEL IMAGING APPLICATIONS}

6718 OC 3D image analysis for evaluating internal deformation/fracture characteristics of materials [6718-02]

M. Nakazawa, Y. Aoki, Shibaura Institute of Technology (Japan); H. Toda, M. Kobayashi,

Y. Kawai, Toyohashi Univ. of Technology (Japan)

$67180 \mathrm{D} \quad$ Virtual reality for microassembly [6718-05]

M. Probst, C. Hürzeler, R. Borer, B. J. Nelson, ETH Zürich (Switzerland) 
$6718 \mathrm{OE} \quad$ A classification and verification of real pattern defects with dust filtering in tape substrate inspection [6718-06]

Y. J. Roh, C. W. Kim, J. Y. Yeom, C. O. Jung, D. H. Jeong, LG Electronics (South Korea)

6718 OF Classification of remote sensing images from urban areas using Laplacian image and Bayesian theory [6718-13]

B. Yousefi, S. M. Mirhassani, H. Marvi, Shahrood Univ. of Technology (Iran)

\section{SESSION 4 TRACKING AND DETECTION TECHNIQUES}

$6718 \mathrm{OH}$ Motion tracking and analysis system for magnetotactic bacteria [6718-03]

M. Mankiewicz, S. Martel, École Polytechnique de Montréal (Canada)

$6718013 D$ measurement of human upper body for gesture recognition [6718-07]

K. Wan, H. Sawada, Kagawa Univ. (Japan)

6718 0J Event detection for car park entries by video-surveillance [6718-15]

D. Coquin, LISTIC, Domaine Univ. (France); J. Tailland, M. Cintract, EBOO Solutions (France)

6718 OK Digital scorebook: football logging and visualization using image processing support [6718-17]

H. Ohki, Oita Univ. (Japan); S. Inove, Japan Broadcasting Corp. (Japan); Y. Fujita,

N. Sueda, Oita Univ. (Japan)

671800 Detection method of skin region by single band pass filter [6718-20]

T. Watanabe, K. Yamamoto, K. Kato, Gifu Univ. (Japan); S. Kojima, S. Nakanishi, Toyota Central R\&D Labs. (Japan)

Author Index 


\title{
Conference Committee
}

\author{
Conference Chair \\ Jonathan Kofman, University of Waterloo (Canada) and \\ University of Ottawa (Canada) \\ Conference Cochairs
}

Yuri Lopez de Meneses, Ismeca Semiconductor Inc. (Switzerland) Shun'ichi Kaneko, Hokkaido University (Japan)

Claudio A. Perez, Universidad de Chile (Chile)

Didier Coquin, LISTIC, Domaine Universitaire (France)

Program Committee

Paul Beardsley, Mitsubishi Electric Research Laboratory (USA)

John Billingsley, University of Southern Queensland (Australia)

Jan Boehm, Universität Stuttgart (Germany)

Yeong-Ho Ha, Kyungpook National University (South Korea)

Seiji Hata, Kagawa University (Japan)

Dieter Just, EUMETSAT (Germany)

Hiroyasu Koshimizu, Chukyo University (Japan)

Kazuhiko Sumi, Kyoto University (Japan)

Jun'ichi Yamaguchi, Kagawa University (Japan)

Session Chairs

1 Image Focus, Enhancement, Distortion, and Encoding

Didier Coquin, LISTIC, Domaine Universitaire (France)

2 3D Range Sensing and Imaging

Jonathan Kofman, University of Waterloo (Canada) and University of Ottawa (Canada)

3 Novel Imaging Applications

Shun'ichi Kaneko, Hokkaido University (Japan)

$4 \quad$ Tracking and Detection Techniques

Yuri Lopez de Meneses, Ismeca Semiconductor Inc. (Switzerland) 
Downloaded From: https://www.spiedigitallibrary.org/conference-proceedings-of-spie on 25 Apr 2023

Terms of Use: https://www.spiedigitallibrary.org/terms-of-use 


\section{International Symposium on Optomechatronic Technologies ISOT 2007}

In recent years, most engineered products, processes, and systems have been evolving towards higher functionality, flexibility, intelligence, and miniaturization. This trend is stimulated by the ongoing fusion between optical and mechatronic technologies leading not only to enhanced performance but also to the creation of new, innovative functionalities. Because of its synergistic effect, the integration of these engineering fields, labeled optomechatronic technology, is becoming a major driving force to future enabling technologies.

The objective of this symposium is to gather researchers and engineers working in the field of optomechatronics and to provide them with a forum for discussion for exchanging their points of view and experience and sharing their research results through high quality peer reviewed papers.

The symposium consists of five conferences:

1) Optomechatronic Actuators and Manipulation

2) Optomechatronic Sensors and Instrumentation

3) Optomechatronic Micro / Nano Devices and Components

4) Optomechatronic Computer-Vision Systems

5) Optomechatronic Systems Control

Symposium Chair

Jean-Marc Breguet, Swiss Federal Institute of Technology, Lausanne (Switzerland)

Symposium Cochairs

Hyungsuck Cho, Korea Advanced Institute of Science and Technology (South Korea)

Shun'ichi Kaneko, Hokkaido University (Japan)

Yoshitada Katagiri, The University of Tokyo (Japan)

Jonathan Kofman, University of Waterloo (Canada) and University of Ottawa (Canada)

George K. Knopf, The University of Western Ontario (Canada)

Rainer Tutsch, Technische Universität Braunschweig (Germany)

John T. Wen, Center of Automation Technologies and Systems,

Rensselaer Polytechnic Institute (USA) 


\section{Steering Committee}

Hyungsuck Cho, Korea Advanced Institute of Science and Technology (South Korea)

George K. Knopf, The University of Western Ontario (Canada)

Farrokh Janabi-Sharifi, Ryerson University (Canada) and University of Tabriz (Iran)

Jonathan Kofman, University of Waterloo (Canada) and University of Ottawa (Canada)

Katsuo Kurabayashi, University of Michigan (USA)

Kee S. Moon, San Diego State University (USA)

Rainer Tutsch, Technische Universität Braunschweig (Germany)

Shun'ichi Kaneko, Hokkaido University (Japan)

Yasuhiro Takaya, Osaka University (Japan)

Yoshitada Katagiri, The University of Tokyo (Japan)

Yukitoshi Otani, Tokyo University of Agriculture and Technology (Japan)

Toru Yoshizawa, Saitama Medical University (Japan) 


\section{Introduction}

Computer-vision systems are being developed and employed in an increasing range of applications from surveillance and security to manufacturing and industry, archaeology, entertainment, and medicine. Recent advances in research and development of vision-based sensors and systems have been the result of advances in both computer-vision and optical-system design, and the innovative fusion of these technologies. Optomechatronic computer-vision systems have evolved in intelligent robot-vision systems, automated inspection, autonomous tracking systems, medical, biological, and agricultural imaging and diagnosis, and novel biometric techniques, to name only a few areas. Improved technology in optical devices and computer-vision techniques has led to increased intelligence and capabilities of new systems. This conference will bring together scientists from academia and industry to exchange the latest ideas and newest techniques, principles, and applications related to optomechatronic computer-vision systems.

Jonathan Kofman 
Downloaded From: https://www.spiedigitallibrary.org/conference-proceedings-of-spie on 25 Apr 2023

Terms of Use: https://www.spiedigitallibrary.org/terms-of-use 